\title{
Geoelectrical investigation for the assessment of groundwater conditions: a case study
}

\author{
Gholam R. Lashkaripour $\left({ }^{1}\right)$ and Mohammad Nakhaei $\left(^{2}\right)$ \\ (') Department of Geology, University of Sistan and Baluchestan, Zahedan, Iran \\ $\left(^{2}\right)$ Department of Geology, University of Tarbiat Moallem, Tehran, Iran
}

\begin{abstract}
An electrical resistivity survey involving Vertical Electrical Soundings (VES) was carried out in the Shooro Basin in Southeast Iran in order to study groundwater conditions such as depth, thickness and aquifer boundaries. Vertical electrical soundings by Schlumberger array were conducted in this area. The resistivity Schlumberger soundings which have a maximum current electrode spacing (AB) ranging from $200 \mathrm{~m}$ to $600 \mathrm{~m}$ were carried out at 207 positions in 19 profiles. Interpretation of these soundings indicates the presence of an alluvial aquifer. This aquifer is divided into eastern and western parts by the Shooro River, which comprises a variable thickness and resistivity of deposits. The average permeability coefficient and resistivity in the western part, especially southwest is higher than the eastern part of the aquifer. Therefore, it seems that Shooro River follows a fault zone in the region. The high resistivity of west part is due to the water quality and the existence of alluvial fan with coarse grain materials. Low aquifer resistivities in the east are associated with finer materials and also brackish water infiltration from the adjacent basin mainly in the central part of the aquifer. Furthermore, zones with high yield potential have been determined in this research based on the resistivity data.
\end{abstract}

Key words electrical resistivity - sounding - groundwater condition - Shooro - Iran

\section{Introduction}

The Shooro Basin that lies in Southeast Iran is located in Sistan and Baluchestan Province. The elevation of the basin is in the range of a minimum of $1360 \mathrm{~m}$ above the mean sea level in north to a maximum of $2960 \mathrm{~m}$ above the mean sea level in the southeast.

The study area lies in the north of the basin about $80 \mathrm{~km}$ in the southwest of Zahedan city, the

Mailing address: Dr. G.R. Lashkaripour, Department of Geology, University of Sistan and Baluchestan, P.O. Box 161-98135, Khash Road, Zahedan, Iran; e-mail: Lashkarg@hamoon.usb.ac.ir capital of Sistan and Baluchestan Province $\left(29^{\circ} 00^{\prime} \mathrm{N}-29^{\circ} 12^{\prime} \mathrm{N}\right.$ and $60^{\circ} 05^{\prime} \mathrm{E}-60^{\circ} 55^{\prime}$; fig. 1), and covers about $210 \mathrm{~km}^{2}$. A nearly flat plain with bedrock outcrops characterizes this area by a mild relief, with slops between 30 to $40 \mathrm{~m}$ topographic contours in the south and central parts.

The purpose of this paper is to use the resistivity data and interpreting geoelectrical soundings to study the aquifer conditions. The use of electrical resistivity for both groundwater resource mapping and for water quality evaluations has increased dramatically over recent decades in much of the world due to the rapid advances in microprocessors and associated numerical modeling solutions. The VES has proved very popular with groundwater studies due to simplicity of the technique.

Water resources of the study area are threatened by increasing population trend with a resulting increase in water demand and the stress- 

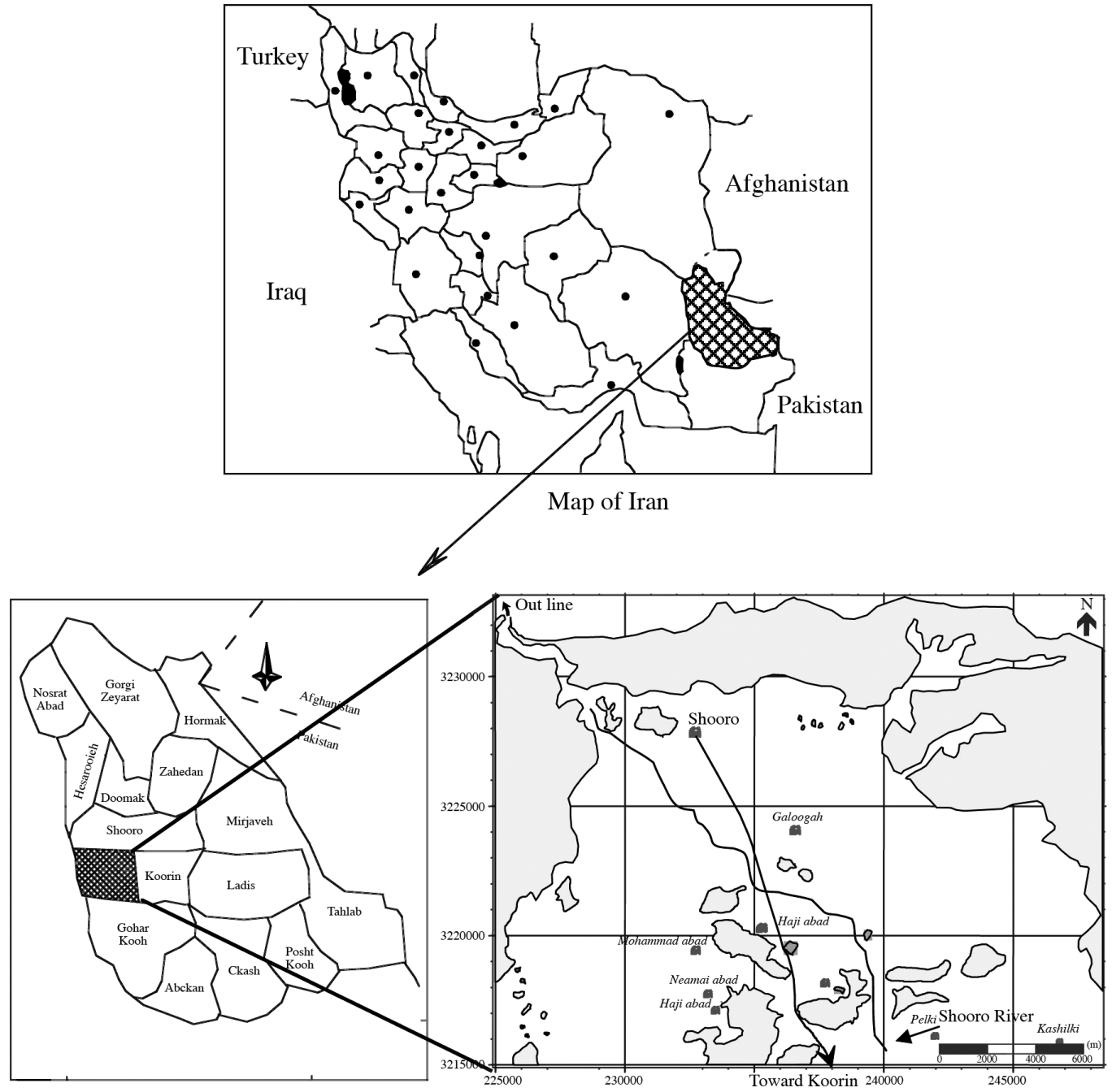

Fig. 1. Location of the studied area.

es of water use for various activities. The need for this research is to study groundwater conditions and to protect groundwater supplies as a unique source of water for this area.

\section{Geological background}

From the geological point of view, Shooro Basin is situated in the Flysch zone of Eastern
Iran. The major portions of the Flysch zone consist of shale, sandstone and limestone. In the Flysch zone, sediments of older than Cretaceous age are absent (Tirrul et al., 1983; McCall, 1997).

Approximately the total bedrock of the aquifer consists of shale and slats mainly green of poor permeability, in the age of Upper Cretaceous and partly Eocene. In the west part of the basin, major outcrop consists of sandstone, shale and philit. Quaternary sediments cover the study 
area. The Quaternary deposits which cover the plain area are composed mainly of fine grain alluvium of Shooro River, gravel to pebble of alluvial fan, sand to gravel and rock debris of the nearby mountains (Geological Survey of Iran, 1995).

\section{Hydrogeological conditions}

The study area is characterized by an arid climate with extremely low rainfall (average 84 $\mathrm{mm} / \mathrm{yr}$ ) and with high evaporation rate (Lashkaripour, 2000). The scanty rainfall is confined to the winter season and rain usually occurs as thunderstorms and showers. The fresh groundwater in the region is originated from infiltration of rainwater, which has created the unconfined Shooro aquifer in the study area.

The Shooro aquifer is the major exploited aquifer in this region and it is an alluvial deposit aquifer. This aquifer is divided into east and west parts by the Shooro River, which comprises a variable thickness of deposit. The average permeability coefficient in the west part is higher than that in the east. Therefore, it seems that Shooro River follows a fault zone in the region.

The aquifer is mainly recharged by the annual rainfall, and discharges naturally by underflow to the Shooro River. It is also discharged artificially through a number of dug wells and galleries called qanat. The newly drilled wells in north and central parts of the aquifer are now used to supply water for agricultural purposes and drinking water to the villages. Rapid agricultural development in the study area has led to increased on demand for water supply. The monitoring of the groundwater level exhibits a decreasing trend of water level. The main reason responsible for this lowering of the groundwater table is that the wells pumping from groundwater resources have exceeded natural recharge in the recent years.

The present study is based on data from the vertical electrical soundings that carried out during April to June 2001; lithological and hydrogeological information from 13 wells; chemical analyses of groundwater samples from the available boreholes. These data are used to evaluate the subsurface hydrogeological and structural
Table I. Hydraulic parameters of the aquifer.

\begin{tabular}{lccc}
\hline \hline No. & Parameters & East part & West part \\
\hline 1 & Aquifer thickness $(\mathrm{m})$ & 24 & 40 \\
2 & Average groundwater & 23 & 41 \\
& $\begin{array}{c}\text { depth from ground } \\
\text { level }(\mathrm{m})\end{array}$ & & \\
& Aquifer resistivity $(\mu \mathrm{m})$ & 12 & 45 \\
3 & EC range $\left(\mu \mathrm{s} \mathrm{cm}^{-1}\right)$ & $2800-9600$ & $760-2500$ \\
5 & Storage coefficient $(\%)$ & 25 & 10 \\
\hline
\end{tabular}

conditions to a depth of about $150 \mathrm{~m}$. In addition, estimation of the groundwater quality and recommendation for possible site-selections for drilling productive wells will be made. The aquifer hydraulic parameters are shown in table I.

\section{Geoelectrical resistivity survey}

Geoelectrical resistivity techniques are popular and successful geophysical exploration for study groundwater conditions in the world. The resistivity of material depends on many factors such as groundwater, salinity, saturation, aquifer lithology and porosity. For example, the resistivity of an aquifer is related to Electrical Conductivity (EC) of its water. When the groundwater EC is high, the resistivity of the aquifer could reach the same range as a clayey medium and the resistivity parameter is no longer useful to determine the aquifer (Vouillamoz et al., 2002). However, this method has been carried out successfully for exploration of groundwater. This technique is widely used to determine depth and nature of an alluvium, boundaries and location of an aquifer.

The resistivity method was used to solve more problems of groundwater in the types alluvium, karstic and another hard formation aquifer as an inexpensive and useful method. Some uses of this method in groundwater are: determination of depth, thickness and boundary of an aquifer (Zohdy, 1969; and Young et al. 1998), determination of interface saline water and fresh water (El-Waheidi, 1992; Yechieli, 2000; and Choudhury et al., 2001), porosity of aquifer (Jackson et al., 1978), water content in aquifer (Kessels 


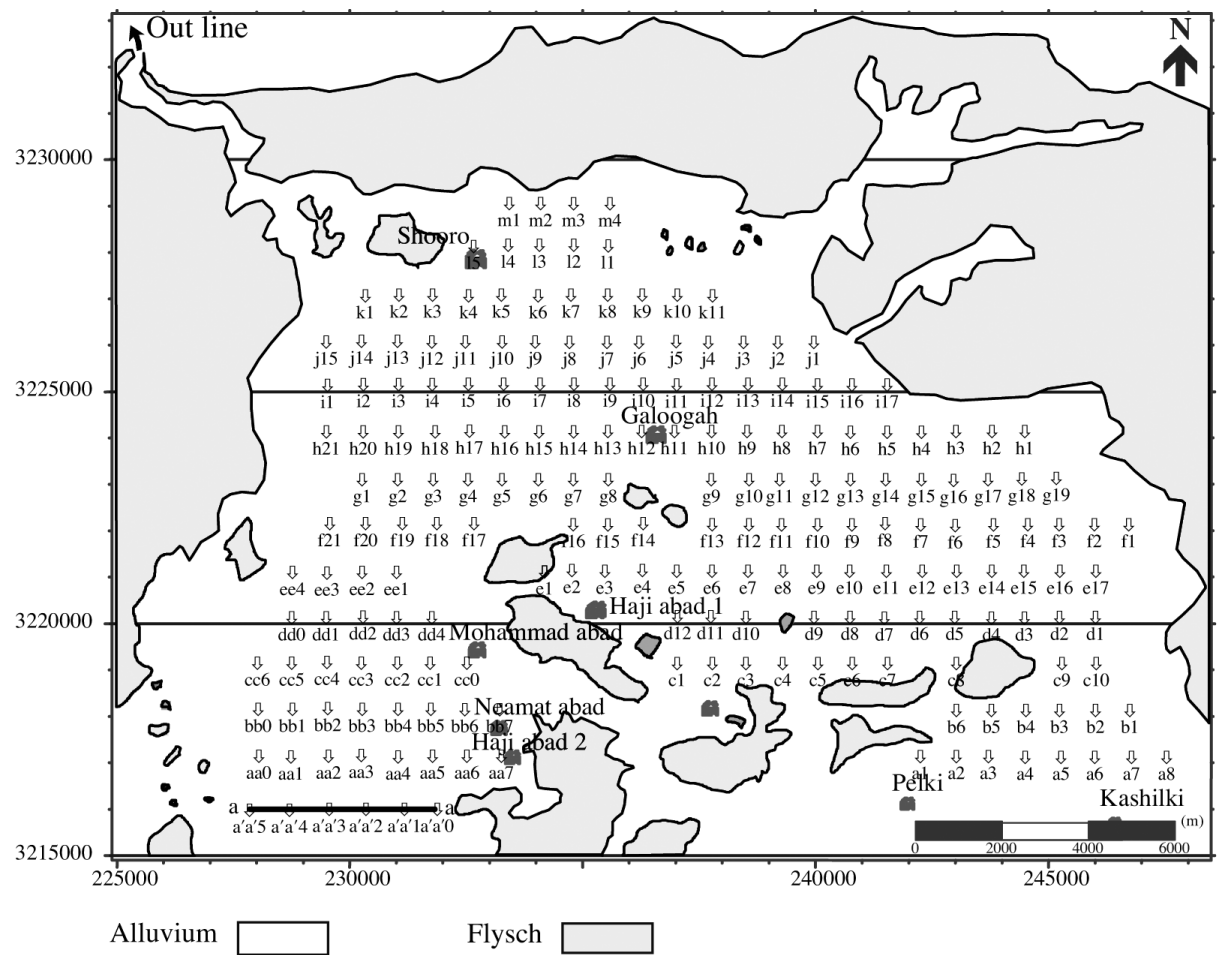

Fig. 2. The location of VES and aa' profile.

et al., 1985), hydraulic conductivity of aquifer (Yadav and Abolfazli, 1998; Troisi et al. 2000), transmissivity of aquifer (Kosinski and Kelly, 1981), specific yield of aquifer (Frohlich and Kelly, 1987), contamination of groundwater (Kelly, 1976; and Kaya, 2001). Contamination usually reduces the electrical resistivity of pore water due to increase of the ion concentration (Frohlich and Urish, 2002). However, when resistivity methods are used, limitation can be expected if ground inhomogeneties and anisotropy are present (Matias, 2002).

This research project deals with detecting the aquifer conditions and groundwater quality in the study area. The resistivity survey was completed with 207 Vertical Electrical Soundings (VES) by the Schlumberger array in 19 profiles, with a maximum current electrode spacing $(A B)$ ranging from 200 to $600 \mathrm{~m}$. The profile spacing was $1 \mathrm{~km}$ and sounding spacing was $750 \mathrm{~m}$. Five of these VES have been conducted adjacent to the dug wells for subsequent calibration process. Position and extension of all the VES's are indicated in fig. 2. Twenty nine geoelectrical sections were drawn along the profiles. The apparent resistivity measurements were made with a KD Sound 7800B Terrameter Unit. This equipment is light and powerful for deep penetration.

\section{Discussion}

The VES curves were obtained by plotting the apparent resistivity against electrode spacing. The resistivity for each of the vertical electrical sounding was drawn on transparent double log graph paper and a smooth field curve.

Computer programs for reducing geoelectrical sounding curves into values of thickness and 
resistivity of individual layers are described by Koefoed (1979) and Zohdy and Bisdorf (1989). The field curves were interpreted by the wellknown method of curve matching with the aid of Russian software IPI7.63. However, the thickness and characteristics of the aquifer are fairly well known due to the number of wells dug in the center of the aquifer. A number of geoelectric stations were purposely located near about 13 wells. The key to success of any geophysical survey is the calibration of the geophysical data with hydrogeological and geological ground truth information.

VES success must rely on the careful interpretation and integration of the results with the other geologic and hydrogeologic data for the site. Therefore, lithologic information obtained from log could be used to calibrate the VES field curves. Where test hole-log information was available, the solution to automatic interpretation procedure was constrained by keeping known layer thicknesses constant during the program computations.

Lastly, the results of the Schlumberger electrical soundings were compared with the geological sections obtained from 13 pizometer wells. These results are in a good agreement with the geological sections. Measuring the current penetration depth was calculated by a correlation between depth and $A B / 2$ as shown in fig. 3. From this figure eq. (5.1) was obtained to calcutate depth of current penetration

$$
\text { Depth }=0.57(A B / 2)^{0.97} \text {. }
$$

From eq. (5.1), the current penetration depth is equal to approximately $A B / 4$.

The boundary of the aquifer, thickness and resistivity of subsurface layers was also determined by the electrical survey in this research. From the interpretation of the resistivity curves a four-layer resistivities and thicknesses indicated four subsurface layers. These layers consisting of surface layer (topsoil), alluvium, saturated layer, and bedrock. In some cases more than one layer was evident in the saturated zone but these cases were also treated in this analysis as single layers. Depth and thickness of subsurface layers were identified and dimension of the aquifer and type of bedrock were also indicated. Bedrock of the area is generally slat but in some parts has appeared as shale. For example, the geoelectrical section of profile aa' in the central west of aquifer is shown in fig. 4 .

The aquifer consists of two main east and west parts that is separated along the Shooro River. The thickness of the aquifer and depth of bedrock is different in the two parts. Average resistivity of the thin top layer, alluvium, aquifer and bedrock calculated in the east as 70 , 74,12 and $113 \Omega-\mathrm{m}$ and in the west as 175,116 , 46 and $106 \Omega-m$ respectively. These data indicate that bedrock in both sides of the aquifer is the same, but permeability and storage coefficient in the eastern part is higher. Depth and

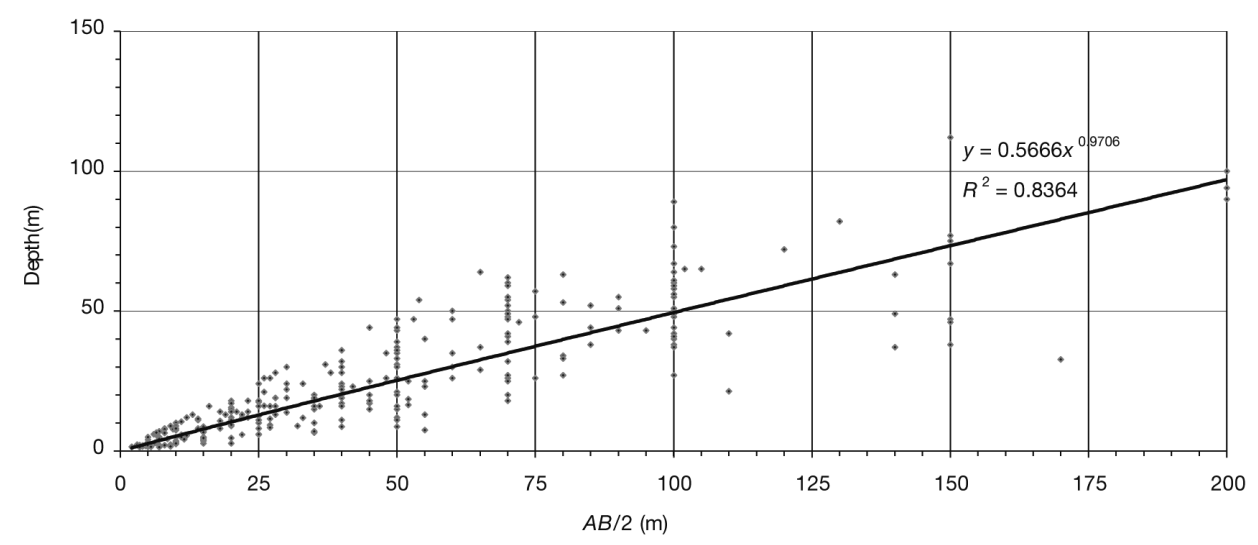

Fig. 3. Correlation between depth of current penetration and length of current electrodes. 


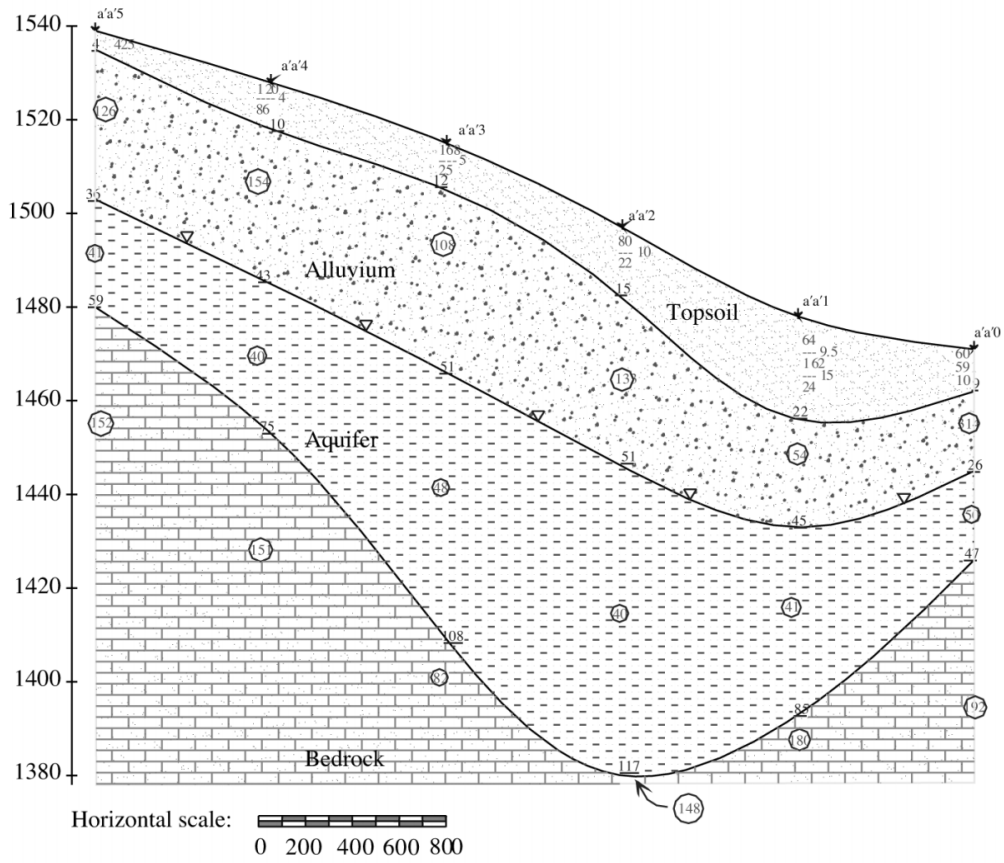

Fig. 4. Geoelectrical section of profile aa'.

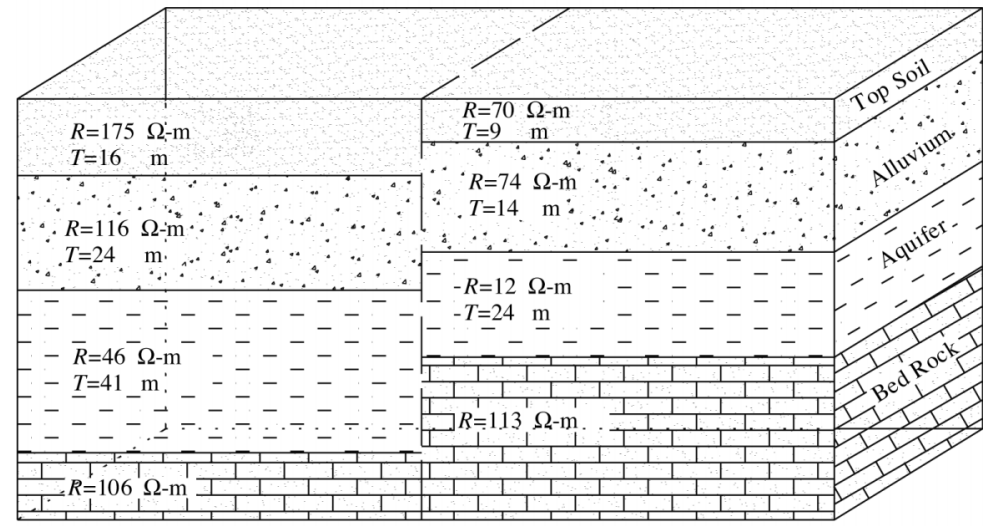

Fig. 5. Subsurface layers in the eastern and western parts of the aquifer. $T$ - thickness; $R$ - resistivity.

thickness of the aquifer were measured in the east as 23 and $24 \mathrm{~m}$ and in the west as 40 and $41 \mathrm{~m}$ respectively (fig. 5). The higher resistivity in the west part is due to the existence of an alluvial fan that consists of a mixture of gravel, sand and silt. The lower resistivity in the eastern part is due to intering of brackish water (EC in the range of 2800 to $9600 \mu \mathrm{s} \mathrm{cm}^{-1}$ ) from an 


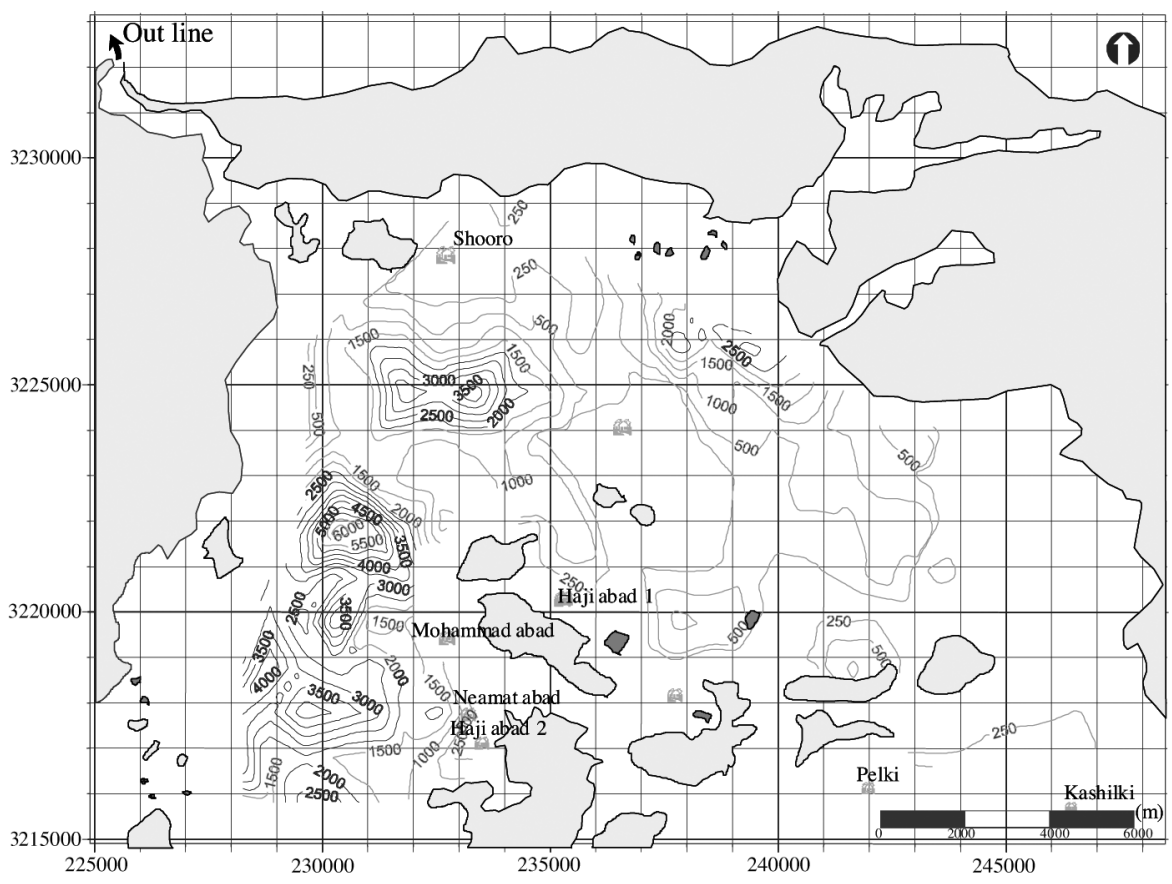

Fig. 6. RT map of the aquifer.

adjacent basin and finer materials of sand and silt mixed with clay.

Yield potential in the western part of the aquifer is more than the eastern part. RT map (Aquifer Resistivity multiply by Aquifer Thickness) that shows the potential of the aquifer for water resources and quality in the whole study area is shown in fig. 6 . The best part of the aquifer for future development is the central portion of the west part of the aquifer. In this part, the best water quality and quantity of groundwater sources are found with respect to high thickness and resistivity. Furthermore, the boundary of the aquifer and type of the bedrock were indicated based on the geoelectrical data.

\section{Conclusions}

This study reveals that surface electrical measurements are effective to study groundwater conditions. Based on the interpretation of geoelectrical data, the following conclusions are drawn:

1) The alluvial aquifer mainly consists of gravel and sand in the west part and sand and silt mixed with clay materials in the east part. The resistivity of the aquifer increases towards the west due to decreasing salinity of water and/or clay content.

2) VES tests revealed four subsurface geoelectric layers; thin top layer, the alluvium, the aquifer and the bedrock respectively.

3) The aquifer thickness increases towards the west, the regional direction of increasing deposition in the basin. The average thickness of the saturated alluvial aquifer in the west part has been estimated about $40 \mathrm{~m}$ and in the east about $24 \mathrm{~m}$.

4) The bedrock of the aquifer shows different resistivity values due to type of bedrock and respect to degree of saturation and values of fractures.

5) The boundary of the aquifer has been estimated and zones with high yield potential have 
been determined for future development in the basin and for choosing drilling sites.

6) The resistivity data of the aquifer shows a decrease in the eastern part due to the intrusion of low quality (saline) water from the adjacent basin.

\section{Acknowledgements}

The research presented in this paper has been supported by a grant from the Sistan Baluchestan Province Water Organization of the Ministry of Power, for which we express our sincere thanks.

\section{REFERENCES}

Apparao, A. and T.G. Rao (1974) Depth of investigation in resistivity methods using linear electrodes, Geophys. Prospect., 22, 211-223.

Choudhury, K., D.K. Saha and P. Chakraborty (2001): Geophysical study for saline water intrusion in a coastal alluvial terrain, J. Appl. Geophys., 46, 189-200.

DARVISHZADEH, A. (1981): Geology of Iran (Nasher Danesh Emrooz Publisher), (in Persian).

El-Waheidi, M.M., F. Merlanti and M. Pavan (1992): Geoelectrical resistivity survey of the central part of Azraq Basin (Jordan) for identifying saltwater/freshwater interface, J. Appl. Geophys., 29, 125-133.

FroHLICH, R.K. and W.E. KelLY (1987): Estimates of specific yield with the geoelectric resistivity method in glacial aquifers, J. Hydrol., 97, 33-44.

Frohlich, R.K. and D. Urish (2002): The use of geoelectrics and test wells for the assessment of groundwater quality of a coastal industrial site, J. Appl. Geophys., 50, 261-278.

Geological Survey of Iran (1995): Geological Map of Khash, Scale 1:250000.

JACKSON, P.N., S.D. TAYLOR and P.N. STANFORD (1978): Resistivity- porosity-particle shape relationships for marine sands, Geophysics, 43, 1250-1268.

KAYA, G.K. (2001): Investigation of groundwater contamination using electric and electromagnetic methods at an open waste-disposal site: a case study from Isparta, Turkey, Environ. Geol., 40, 725-731.

KeLLY, E.W. (1976): Geoelectric sounding for delineating ground water contamination, Ground Water, 14, 6-11.

Kessels, W., I. FlentGe and H. Kolditz (1985): DC geo- electric sounding to determine water content in the salt mine asse (FRG), Geophys. Prospect., 33, 456-446.

Koefoed, O. (1979): Geosounding Principles, 1. Resistivity Sounding Measurements (New York, NY, Elsevier Scientific Pub. Co.), pp. 276.

KossinsKI, W.K. and W.E. Kelly (1981): Geoelectric sounding for predicting Aquifer Properties, Ground Water, 19, 163-171.

LASHKARIPOUR, G.R. (2000): Groundwater pollution of Zahedan city in the East of Iran, J. Nepal Geol. Soc., 21, 99-102.

MAtias, M.J.S. (2002): Squary array anisotropy measurements and resistivity sounding interpretation, J. Appl. Geophys., 49, 185-194.

McCALL, G.J.H. (1997): The geotectonic history of Makran and adjacent area of Southern Iran, J. Asian Earth Sci., 15, 517-531.

Tirrul, R., I.R. Bell, R.J. GrifFis and V.E. CAmp (1983): The Sistan suture zone of Eastern Iran, Geol. Soc. Am. Bull., 94, 134-150.

Troisi, S., C. Fallicos, S. Straface and E. Migliari (2000): Application of kriging with external drift to estimate hydraulic conductivity from electrical resistively data in unconsolidated deposits near Montato Uffugo, Italy, Hydrogeol. J., 8, 356-367.

VINCENZ, S.A. (1968): Resistivity investigations of limestone aquifers in Jamaica, Geophysics, 33, 980-994.

Vouillamoz, J.M., M. Descloitres, J. Bernard, P. FourCASSIER and L. ROMAGNY (2002): Application of integrated magnetic resonance sounding and resistivity methods for borehole implementation. A case study in Cambodia, J. Appl. Geophys., 50, 67-81.

YADAV, G.S. and H. ABOLFAZLI (1998): Geoelectric soundings and their relationship to hydraulic parameters in semiarid regions of Jalore, Northwestern India, J. Appl. Geophys., 39, 35-51.

YECHIELI, Y. (2000): Fresh-saline ground water interface in the Western Dead Sea area, Ground Water, 38, 615-623.

Young, M.E., R.G.M. DE BRUIJIN and A. SALIM Al-IsMAILY (1998): Reports: exploration of an alluvial aquifer in Oman by time-domain electromagnetic sounding, $\mathrm{Hy}$ drogeol.J., 6, 383-393.

ZoHDY, A.A.R. (1969): Application of deep electrical soundings for groundwater exploration in Hawaii, Geophysics, 34, 584-600.

Zohdy, A.A.R. and R.J. BisdorF (1989): Programs for the automatic processing and interpretation of Schlumberger sounding curves in Quick Basic, U.S. Geol. Surv. Open File Rep. 89-137-2, p. 64.

(received January 24, 2005; accepted November 28, 2005) 